Hypoadiponectinemia is an independent risk factor for hypertension. Hypertension 2004; 43: 1318-1323

38) Pischon T, Girman CJ, Hotamisligil GS et al: Plasma adiponectin levels and risk of myocardial infarction in men. JAMA 2004; 291: 1730-1737

39) Efstathiou SP, Tsioulos DI, Tsiakou AG et al: Plasma adiponectin levels and five-year survival after first-ever ischemic stroke. Stroke 2005; 36: 1915-1919
40) Maeda N, Takahashi M, Funahashi T et al: PPARgamma ligands increase expression and plasma concentrations of adiponectin, an adipose-derived protein. Diabetes 2001; 50(9): 2094-2099

41) Kurata A, Nishizawa H, Kihara $S$ et al: Blockade of AT1 receptor reduces oxidative stress in adipose tissue and ameliorates adipocytokine dysregulation. Kid Int (in press)

\title{
用圄圈説 血管老化
}

加㱓による血管の老化はさまざまな心血管 疾患の罹患率を増大させる，とくに高齢者に おける収縮期血圧の増大と脈圧の増大は，血 管老化の主要な指標であり, 重要な心血管疾 患の危険因子である.

ヒトは加齢に伴い動脈壁厚の增加や内腔の 拡大などの構造変化を示すようになる．動脈 壁厚の増加は, 内膜の肥厚によって引き起こ されるが，それにはコラーゲンを主成分とす る細胞外基質, 平滑筋細胞, 単核球細胞など が含まれる，内膜の肥厚には，老化に伴う炎 症性サイトカインや増殖因子の発現の充進が 関与している。これらの構造変化は，血管老 化の主要な指標の一つである血管のコンプラ イアンス低下に関与している.

加齢に伴う血管の变化は，構造変化のみで はなく，さまざまな機能異常を含んでいる. 内皮依存性の血管拡張反応は, 脈圧が増大し はじめる年龄において有意に低下していく. アセチルコリンを冠動脈に投与すると通常は
内皮依存性の血管拡張反応が生じることによ って冠動脈血流が増大するが，高齢者では有 意に低下する，その主要な原因は，血管内皮 細胞に打ける一酸化窒素（NO）の産生の低 下であると考えられている。 $\beta$ アドレナリン 作動性の薬剤は，血管平滑筋に直接作用して 内皮非依存性の血管抎張反応を引き起こす が，その反応も加齢に伴い低下していること が示されている.

加齡に伴い易血栓性がえ進し, 心血管疾患 の発症を増加させていると考えられている が，それには血液中の凝固系や血小板機能の 異常だけではなく，抗血栓作用を含む内皮機 能の障害も関与している.これらの老化に伴 う血管の形態変化や機能変化が引き起こされ るメカニズムとして，最近血管紐胞レベルの 老化 (cellular senescence) の関与が注目さ れている.

(千葉大学大学院医学研究院循環病態医科学

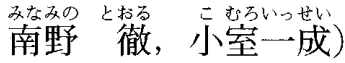

